International Journal of Instruction

e-ISSN: 1308-1470 • www.e-iji.net

Article submission code:

2020030603475

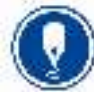

Received: 06/03/2020

Revision: 09/10/2020
April 2021 • Vol.14, No.2

p-ISSN: 1694-609X

pp. 627-646

Accepted: 01/11/2020

OnlineFirst: 14/02/2021

\title{
The Development of Creative Cognitive-Behavior Counseling Model as a Strategy to Improve Self-Regulated Learning of Student
}

\section{Wahyu Nanda Eka Saputra}

Universitas Ahmad Dahlan, Indonesia, wahyu.saputra@bk.uad.ac.id

Said Alhadi

Universitas Ahmad Dahlan, Indonesia, said.alhadi@bk.uad.ac.id

\section{Agus Supriyanto}

Universitas Ahmad Dahlan, Indonesia,agus.supriyanto@bk.uad.ac.id

\section{Sofwan Adiputra}

Universitas Muhammadiyah Pringsewu Lampung, Indonesia, sofwan@konselor.org

Students in schools need the ability to self-regulated learning (SRL) to support academic achievement. This study aims to identify the acceptance of the Creative Cognitive-Behavior Counseling Model (CCBCM) based on expert guidance and counseling and product effectiveness testing. CCBCM is an integration of Cognitive Behavior Counseling (CBC) with creative art. The type of research used is research and development $(\mathrm{RnD})$ by adapting the Borg and Gall formula which is limited to stages (1) problem identification; (2) formulation of a hypothetical draft model; (3) product feasibility testing by experts in guidance and counseling; (4) product revision; (5) test product effectiveness. The instrument used in this study was a self-regulated learning scale (SRLS) and expert assessment sheets about product viability. The results from the study concluded that CCBCM was categorized as feasible to be applied by school counselors to develop students' SRL based on assessments by expert guidance and counseling. CCBCM can also effectively improve students' SRL. Counselors can use CCBCM as a counseling strategy to enhance students' SRL at school.

Keywords: academic achievement, cognitive behavior counseling, counseling strategy, creative art, self-regulated learning

\section{INTRODUCTION}

Character education in the era of industrial revolution 4.0 emphasizes the development of character strength in students. The power of this character is a manifestation of the concept of positive psychology, where one needs to see the right side rather than just seeing the wrong side of someone (Banicki, 2014; Niemiec \& Wedding, 2014). The strength of student character supports subjective well-being in adolescents (Gillham et al., 2011; Oliveira et al., 2016; Yasmin, Natasha; Khan, 2017).

Citation: Saputra, W. N. E., Alhadi, S., Supriyanto, A., \& Adiputra, S. (2021). The Development of Creative Cognitive-Behavior Counseling Model as a Strategy to Improve Self-Regulated Learning of Student. International Journal of Instruction, 14(2), 627-646. https://doi.org/10.29333/iji.2021.14235a 
One of the strengths that students need to have to navigate the challenge of this age is self-regulation (McGrath, 2015). Self-regulation character is behavior directed at the goals to be achieved by individuals, in which self-regulation has a relationship with selfcontrol (Hofmann et al., 2012). Self-control is one small part of self-regulation (Hagger et al., 2010; Hofmann et al., 2012). Restraint has a goal to set aside impulses that can reduce the chances of achieving the goal. Some examples of self-regulation itself are regulating self-behavior to obtain achievement, personal goals, and reduce individual problems. An individual's failure to develop self-regulation can trigger many social and mental issues (Heatherton \& Wagner, 2011).

The importance of self-regulation in the field of learning becomes an important variable that can facilitate students achieving academic achievement development (McClelland \& Cameron, 2011; McClelland \& Wanless, 2012; T. Vaughn, 2014). The concept of self-regulation in the field of learning is called Self-Regulated Learning (SRL). Students develop the ability of SRL to support the learning process at school. SRL encourages student achievement (Cetin, 2015; Dent \& Koenka, 2016; Wolters \& Hussain, 2015).

However, SRL problems become one of the issues that still occur in students. The results of research on vocational high-school students in Yogyakarta concluded that 7\% of students had very low SRL; $21 \%$ of students have low SRL; $42 \%$ of students have moderate SRL; 23\% of students have high SRL; and 7\% of students have extremely high SRL (Saputra et al., 2018). The low condition of SRL on students has a negative impact if no intervention is given by those who have exclusive competence, which in this case, is the school counselor.

Low SRL hurts students. The impact of low SRL on students is the decrease in student academic achievement (Cetin, 2015). Besides, the low SRL also affects the level of academic performance of students in the learning process at school (Keyser \& Viljoen, 2015; Lucieer et al., 2016). Other studies have concluded that low SRL has a broader impact, namely students' difficulties in achieving academic success (Bruso \& Stefaniak, 2016; Sun et al., 2018).

Low SRL does not occur by itself but because of certain factors, namely the dysfunctional student's mind. Students who have low SRL tend to think dysfunctionally, so they cannot bring up a belief that they can do learning independently and optimally (Bjork et al., 2013). In other words, their dysfunctional thoughts are judgments about themselves that they are not able to complete a task with their abilities (Pajares, 2002).

Therefore, the intervention used to improve SRL is to implement Cognitive-Behavior Counseling $(\mathrm{CBC})$. This counseling approach combines cognitive counseling with behavior, which assumes that the reorganization of mindset will have an impact on behavioral change (Corey, 2018). The counselor seeks to identify the forms of student thought that cause low levels of SRL and help to turn them into more functional mindsets so that their SRL can improve.

Several studies have shown the influence of CBC in improving students' SRL. The Cognitive-Behavioral Counseling Model online can be used to develop SRL middle school students (Nur Hidayah, 2013). However, not all students can access the use of 
online media and make good use of it. Therefore, CBC needs to be integrated with other elements to increase its effectiveness.

To increase the effectiveness of CBC, it needs to combine with creative arts. Therefore, in this research and development, the combination of creative arts with $\mathrm{CBC}$ is called the Creative Cognitive-Behavior Counseling Model (CCBCM). The CBC integration counseling model with creative arts requires counselors to be able to maximize their creativity and implement counseling services with many possibilities (Alhadi \& Saputra, 2018). Creative art as an element that embodies the creativity of the counselor in providing counseling services to the counselee. Especially in the 21 st century, it brings many new challenges and issues that make individual counseling more relevant and prominent in our society (Gladding, 2011, 2016; C. M. Rosen \& Atkins, 2014).

The integration of $\mathrm{CBC}$ with creative arts aims to achieve changes in behavior in the counselee (Meyer, 2018), which in this case, is an increase in SRL. The integration of $\mathrm{CBC}$ with creative arts is expected to be an innovative counseling model and have a significant impact on behavioral changes in counselees (Alhadi \& Saputra, 2018). CCBCM will provide counselee insights (such as writing or painting) and new ways of counseling that lead to changes in counselee behavior (Gladding, 2016).

More concisely, this study aims to develop CCBCM to improve students' SRL. This research and development formulate into five sub-objectives, namely (1) knowing the level of students' SRL; (2) formulating a hypothetical draft model (3) identifying product viability based on expert judgment and counseling assessments; (4) expressing the final product by making revisions based on the evaluations of guidance and counseling experts; and (5) identify the effectiveness of the product. Future studies can detect the use of creative arts specifically to support CBC to improve student SRL.

\section{CONTEXT AND REVIEW OF LITERATURE}

\section{Self-regulated learning}

SRL is the ability of the human self to manage their learning patterns (Ormrod et al., 2016). SRL has a complex process because it consists of cognitive, motivational, and contextual elements (de Boer et al., 2013). Metacognition is one of the methods that control this element and the basis of self-regulation in learning. Self-regulation in learning is a combination of skills (skills) and desires (will). Strategic learners are learners who learn to plan, control and evaluate their cognitive, motivational or affective, contextual behavior and processes (Mukhid, 1998). Learners who know how to learn are learners who motivate themselves, know their possibilities and limitations, control and regulate learning processes so that they are accustomed to their goals and context, are optimistic about performance, and improve their skills through practice.

Students who can learn based on self-regulation compile a set of performance goals for themselves, give respect to themselves and make criticisms of themselves. A student is said to be able to regulate himself if his thoughts and actions are under his control and not under other people or the environment around him. Zimmerman's definition of SRL includes several characteristics. Namely, students are aware of their self-regulation 
process, know the process to improve academic achievement, provide feedback to themselves during the learning process, and monitor the effectiveness of learning methods or strategies. They have done and have a motivational component (Rosen, Glennie, Dalton, Lennon, \& Bozick, 2010).

SRL has three main factors, namely, self-efficacy, motivation, and goals (Schunk, 2012). Self-efficacy refers to a person's beliefs about one's ability to learn or perform skills at a certain level. Motivation is something that moves an individual towards a goal, with the hope of getting results from that level and the confidence to do it. The objective is the criteria used by individuals to monitor the progress of their learning. Of the many notions of SRL, there are proven components that are most important in contributing to student performance in the classroom, namely metacognitive, motivational, and behavioral (Pintrich \& De Groot, 1990; Zimmerman, 1989).

\section{ССBCM}

The issue of counseling is currently a hot topic in the international world, including in Indonesia. This issue is none other than the cause is the emergence of the various problem's both national and global issues. These problems become one of the stimuli of the decline of the development of adolescents today who are experiencing extreme moral degradation.

The importance of the existence of counseling itself sometimes does not make counseling sessions a fun activity for the counselee. Even counselees will feel bored when dealing with counselors to conduct counseling sessions. One of the counseling factors becoming boring for counselees is that counselors rarely use creative and not multisensory tools (Jacobs, 1992). In other words, counselors often do conventional counseling. This method is often analogous to counseling that does not use creative tools. If the counselor does not use creative tools in counseling, the counselee will slowly leave the counselor. Creative aids in counseling many types, one of which is the current hot theme is creative arts (Gladding, 1992, 2011, 2016).

Counseling itself requires the creativity of the counselor to increase the effectiveness of counseling interventions given to counselees who have problems and make the counseling process not tedious (Cole \& Sarnoff, 1980; Gladding, 1992, 2011, 2016). Counselors are required to be able to appear creative when providing meaningful counseling services for counselees. This demand is not something easy but requires extra effort for the counselor to be able to perform as a creative counselor. Moreover, there is a myth saying that humans are born with two possibilities. Namely, humans are born with creativity, and there are humans born without creativity (Plucker et al., 2004).

There are several reasons why counselors optimize the creative aspects of the counseling process, including, in this case, the CBC. Some ideas include (1) the counselor's primary tool helps the counselee become more integrated (congruence); (2) giving individuals new energy and reinforcement for behavior change; (3) provide motivation for counselees to remain able to focus for the implementation of BK services; (4) making counseling services more artistic (counseling is an art); (5) creating a brand new sense of self in the counselee to recover from adversity; (6) the counselee can conceptualize and 
duplicate useful activities; (7) increase socialization and cooperation; and (8) increasing the counselee's understanding of multiculturalism (Gladding, 2016).

The integration of creative arts with $\mathrm{CBC}$ in this study is called CCBCM. Through the creation of CCBCM, students can symbolically explain and describe their inner and outer world, how they interpret it, and how they feel the problems they experience. Besides, combining art techniques and Cognitive Behavior Counseling is effective in reducing anxiety and increasing confidence in the counselee (Parker-Bell, 2010). This effort is proof that the integration of creative arts in Cognitive Behavior Counseling is essential to do. CCBCM itself covers the following stages, namely (a) problem assessment; (b) looking for root causes that come from negative thoughts; (c) counselors and counselees identify positive and negative consequences; (d) rearranging distorted beliefs; (e) behavioral interventions.

Counseling by involving creative arts and Cognitive Behavior Counseling can be integrated because both require cognitive processes and creativity (Greenberg, 2000). Therefore, participation in counseling that includes creative arts is an opportunity for young people to see their feelings and thoughts. They can also practice solving problems by using new and unknown art materials and try to apply them creatively in an art activity.

\section{METHOD}

\section{Research design}

This research is development research that aims to develop CCBCM as a counselor strategy to improve students' SRL. This research and development adapted the Borg and Gall pattern which is limited to five stages of research and development, namely (1) identification of the level of SRL behavior that is the basis of CCBCM development; (2) preparation of a hypothetical draft of CCBCM products to improve SRL; (3) an evaluation by the expert in guidance and counseling to assess the feasibility of the product; (4) product revisions based on two expert ratings; (5) product effectiveness test (Borg \& Gall, 1983). The design in this product uses a type of quasi-experimental research design that involves two groups, namely the experimental and control groups. In contrast to the true-experimental design, the experimental and control groups in the quasi-experimental research design were not randomly assigned. In the experimental group using CCBCM intervention, and the control group using conventional counseling interventions. Figure 1 below presents a quasi-experimental design.

\begin{tabular}{|c|c|c|c|}
\hline Groups & Pretest & Treatment & Post-test \\
\hline Control & $\mathrm{O} 1$ & & $\mathrm{O} 2$ \\
\hline$\ldots \ldots$ & $\ldots \ldots$ & $\ldots \ldots \quad \ldots$ & $\begin{array}{lll}\ldots \ldots & \ldots & \ldots \ldots\end{array}$ \\
\hline Experimental Group & $\mathrm{O} 1$ & $\mathrm{X}$ & $\mathrm{O} 2$ \\
\hline $\begin{array}{r}\text { Where: } \mathrm{O} 1=\text { Pretest of } \\
\mathrm{O} 2=\mathrm{P} \\
\ldots= \\
\mathrm{X}=\mathrm{In}\end{array}$ & $\begin{array}{l}\text { rol and Ex } \\
\text { est of cont } \\
\text { ndomizat } \\
\text { ntion is gi }\end{array}$ & $\begin{array}{l}\text { roups } \\
\text { imental Gro } \\
\text { s to groups } \\
\text { f treatment }\end{array}$ & \\
\hline
\end{tabular}

Quasi-Experimental research design 


\section{Data collection}

The research instruments used consisted of two types. The first instrument is the SelfRegulated Learning Scale (SRLS), composed of 43 items that have been declared valid with a coefficient of 0.270 to 0.655 after testing the validity of the product-moment correlation formula. While the results of reliability testing using the Cronbach alpha formula showed a coefficient of 0.902 , classified as a very high category of reliability. The SRLS instrument is self-designed. The SRLS involves three aspects, namely, metacognition, motivational, and behaviorally active participants (Zimmerman, 1990). The SRLS is used to measure the level of SRL before and after students are given CCBCM interventions. Table 1 describes aspects and indicators of SRLS instruments.

Table 1

SRLS indicator

\begin{tabular}{ll}
\hline Aspect & Indicator \\
\hline Metacognition & The people have a desire to understand the subject matter received. \\
\cline { 2 - 2 } & Analyzing the subject matter obtained. \\
\hline Motivational & Have a plan for learning programs \\
\cline { 2 - 2 } & Have the determination to carry out the learning schedule \\
\hline $\begin{array}{l}\text { Behaviorally active } \\
\text { participants }\end{array}$ & Having control in carrying out the learning schedule \\
\cline { 2 - 2 } & Apply acquired knowledge \\
\hline
\end{tabular}

While the second instrument is an assessment sheet used by the expert in guidance and counseling to provide a feasibility assessment of the product, namely CCBCM. The expert evaluation sheets consist of 3 aspects, namely a general description of the product, product usability, and product accuracy. The assessment sheet for the product also allows experts to provide criticism and suggestions for the product.

\section{Subject of study}

In the identification stage of the SRL profile, the population involved was 804 students of the Muhammadiyah Vocational Middle School in the city of Yogyakarta, mainly class XI. The population in this study was 415 students. The sampling technique used is stratified random sampling.

In the feasibility testing of the product, it involves two experts in guidance and counseling. The characteristics of the experts to assess the feasibility of this product are (1) having a background in scientific guidance and counseling; (2) has a map of research on counseling innovation; (3) experts in the area of SRL problems.

At the product, the effectiveness tests stage, the subjects involved in this study were students who had very low and low SRL rates. Research subjects involved in the effectiveness test amounted to 12 students who were divided into two groups, namely the experimental and control groups.

\section{Research stages}

There are several stages in the implementation of this research. First, identify the student's SRL level by distributing SRLS instruments to students. The population in this 
study amounted to 804 students. The sampling technique used in this study was stratified random sampling, and the number of samples involved in this study was 415 students. Second, an initial draft of CCBCM to improve students' SRL. This draft covers the characteristics of students' SRL problems and the basic concepts of CBC. Third, a feasibility assessment by experts in guidance and counseling. The feasibility assessment of the product developed by involving an expert assessor, namely a lecturer from the Universitas Ahmad Dahlan, guidance and counseling study program with innovation and guidance counseling expertise. Besides, the assessment was also carried out by an expert in guidance and counseling who knows to provide counseling services to promote behavior change from counselees, primarily SRL. Fourth, respond to criticisms and suggestions that come from experts in the field of guidance and counseling. This revision is to improve product y, namely CCBCM, to improve SRL students. Sixth, the researchers conducted a product trial to test the effectiveness of CCBCM to enhance students' SRL. Seventh, researchers identify the effectiveness of CCBCM in improving students' SRL.

\section{Data analysis technique}

The study uses data analysis techniques in the form of quantitative descriptive with percentages. Analysis of this data for the SRL level assessment of Muhammadiyah Vocational School students in Yogyakarta city, so that it would be known the percentage of students who had SRL levels in the very high, high, medium, low, and very low categories. Besides, the analysis of the inter-rater reliability (IRR) coefficients of Cohens' Kappa describes the level of feasibility of the product, namely CCBCM, to improve student SRL. As for the effectiveness test, the data analysis technique used is the Mann-Whitney $U$ test. This data analysis technique to find out if there is a real difference between the average of two polls with the same distribution, through two independent samples taken from the two populations.

\section{FINDINGS}

The results of this research and development are abstracted into five main parts, namely (1) the student's SRL level; (2) hypothetical draft model; (3) the feasibility of a research product, namely CCBCM to improve students' SRL; (4) revision of the product; (5) product effectiveness test, namely CCBCM to enhance students' SRL.

\section{The student's SRL level}

The identification of SRL Muhammadiyah Vocational high-school students' level in Yogyakarta City, especially in class XI, was done by involving 415 samples taken by stratified random sampling. After a descriptive statistical analysis using SPSS help software on the SRL level, the scores range for very low categories (74-110), low (101116), moderate (117-132), high (133-148), and very high (149-165).

Based on the recapitulation of SRL level measurements, that SRL students are in the very low category by $7 \%$, the low category by $21 \%$, the moderate category by $42 \%$, the high category by $23 \%$, and the very high category by $7 \%$. The results of research on the SRL level indicate that there are still SRL problems experienced by students. The 
question requires a solution. This study seeks to address these problems by developing CCBCM.

\section{Hypothetical draft of CCBCM to enhance SRL}

The hypothetical draft CCBCM was prepared as an initial product of the study. CBC, which is integrated with creative arts is named Creative Cognitive-Behavior Counseling Model (CCBCM). CCBCM includes the following stages, namely (a) problem assessment; (b) looking for root causes that come from negative thoughts; (c) counselors and counselees identify positive and negative consequences; (d) rearranging distorted beliefs; (e) behavioral interventions. The overall model is illustrated in the following chart (Figure 2).

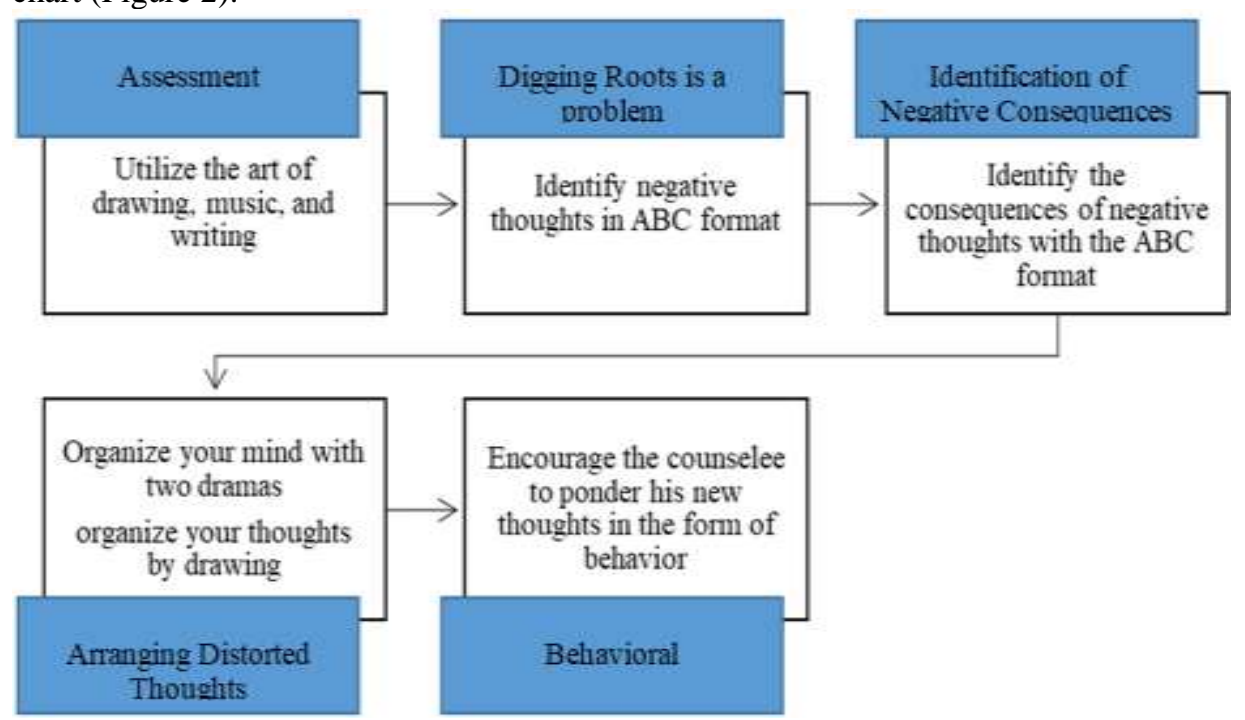

Figure 2

Creative cognitive behavior counseling model (CCBCM)

\section{Feasibility of research products}

CCBCM consists of five stages. This stage guides the counselor to implement CCBCM in the effort of the counselor to help the counselee get out of his problem; in this case, the emphasis is on increasing SRL. The focus on CCBCM is changing the counselee's mindset from negative thinking to be more positive through creative art expression. Changing this mindset can also encourage the counselee to change his behavior. The underlying assumption of Cognitive Behavior Counseling is the reorganization of thoughts and feelings that will bring about the reorganization of behavior in the counselee (Corey, 2018).

Product viability is tested by carrying out assessments by experts in guidance and counseling. The following table displays the results of the product feasibility assessment by experts in guidance and counseling (Table 2). 
Table 2

Results of expert assessment of products

\begin{tabular}{lll}
\hline No & Aspect & Average Value \\
\hline 1 & Product overview & 3.07 \\
\hline 2 & The accuracy of the product for developing SRL students & 3.27 \\
\hline 3 & The usefulness of the product for counselors to develop SRL students & 3.1 \\
\hline
\end{tabular}

This assessment is specially carried out by two experts (lecturer and researcher from the guidance and counseling study program). The average assessment result of expert assessors of the product is 3.18. To identify the feasibility of the product using the interrater reliability (IRR) analysis of the Cohens' Kappa coefficient on the agreement of two assessors. Based on the analysis using SPSS software, the results are as follows (Table $3)$.

Table 3

Analysis of the Cohens' Kappa coefficient

\begin{tabular}{|c|c|c|c|c|}
\hline & Value & $\begin{array}{l}\text { Asymptotic } \\
\text { standard Error }^{a}\end{array}$ & Approximation $\mathrm{T}^{\mathrm{b}}$ & $\begin{array}{l}\text { Approximation } \\
\text { significance }\end{array}$ \\
\hline Measure of Agreement Kappa & .612 & .076 & 7.788 & .000 \\
\hline
\end{tabular}

$\mathrm{N}$ of Valid Cases inter-rater reliability that is $\mathrm{K}=0.612$ with the strong category. The value of Cohen's kappa coefficient means that there is a strong agreement between two experts regarding the feasibility of the product. Asymptotic standard Error indicates standardized measurement errors. The smaller the magnitude of this coefficient, the more reliable the resulting measurement results. The significance value can be seen in the column of approximation significance, which is equal to 0,000 . Because the significance value is smaller than the significance level used by $5 \%(0,000<0.05)$, it is concluded that there is a significant agreement between two experts at a significance level of $5 \%$ for the product.

\section{Product Revision}

The initial product gets some criticism and suggestions from experts who assess the CCBCM hypothetic draft to improve SRL. Ideas from experts and follow-up are in table 4 below.

Table 4

Expert recommendations

\begin{tabular}{llll}
\hline No & Expert 1 & Expert 2 & Follow-up \\
\hline 1 & $\begin{array}{l}\text { The operational phase of the CCBCM } \\
\text { needs to be arranged more operational }\end{array}$ & $\begin{array}{l}\text { There needs to be an } \\
\text { operational implementation } \\
\text { of the CCBCM }\end{array}$ & $\begin{array}{l}\text { Operate every stage of } \\
\text { CCBCM to develop SRL }\end{array}$ \\
\hline 2 & $\begin{array}{l}\text { The integration of CBC and creative arts } \\
\text { needs to be sharpened }\end{array}$ & $\begin{array}{l}\text { The relationship between } \\
\text { CBC and creative arts needs } \\
\text { to be clarified more clearly }\end{array}$ & $\begin{array}{l}\text { Add a rational combination of } \\
\text { CBC with creative arts }\end{array}$ \\
\hline 3 & $\begin{array}{l}\text { The ease of use of the product for users } \\
\text { needs to be explained more operationally }\end{array}$ & $\begin{array}{l}\text { The ease of use of language } \\
\text { should be noted }\end{array}$ & $\begin{array}{l}\text { Readability test conducted by } \\
\text { experts in the field of language }\end{array}$ \\
\hline 4 & $\begin{array}{l}\text { The use of other creative arts, such as } \\
\text { poetry should be considered to strengthen } \\
\text { CCBCM }\end{array}$ & $\begin{array}{l}\text { Add one type of creative art, } \\
\text { namely poetry combined with } \\
\text { CBC }\end{array}$ \\
\hline
\end{tabular}




\section{Test the effectiveness of the product}

The next step is to test the effectiveness of the product. A product effectiveness test to test the effectiveness of CCBCM to improve SRL empirically. Before the treatment is carried out to measure the effectiveness of CCBCM, the first thing to do is to carry out a pretest to measure the student's SRL level before being given treatment at SMK Muhammadiyah 3 Yogyakarta.

Product trials tested the effectiveness of CCBCM to improve student SRL. To test the effectiveness of the product, 12 students who have the lowest SRL level will be two groups. Where one group becomes the control group (gets conventional counseling intervention), and one group becomes the experimental group (gets CCBCM intervention). The following results show the experimental test tables in the experimental and control groups (Table 5).

Table 5

Experimental group student data

\begin{tabular}{llllll}
\hline \multirow{2}{*}{ No } & \multirow{2}{*}{ Name } & Pretest & & Posttest & \\
\cline { 2 - 6 } & & Score & Category & & \\
\hline 1 & KE 1 & 101 & Very low & 131 & Medium \\
\hline 2 & KE 2 & 100 & Very low & 130 & Medium \\
\hline 3 & KE 3 & 108 & Low & 139 & Medium \\
\hline 4 & KE 4 & 99 & Very low & 129 & Medium \\
\hline 5 & KE 5 & 110 & Low & 139 & Medium \\
\hline 6 & KE 6 & 109 & Low & 140 & \\
\hline
\end{tabular}

Tabel 6

Control group student data

\begin{tabular}{llllll}
\hline \multirow{2}{*}{ No } & \multirow{2}{*}{ Name } & Pretest & & Posttest & \\
\cline { 2 - 5 } & & Score & Category & Score & Category \\
\hline 1 & KK 1 & 107 & Low & 111 & Low \\
\hline 2 & KK 2 & 110 & Low & 114 & Low \\
\hline 3 & KK 3 & 101 & Very low & 105 & Low \\
\hline 4 & KK 4 & 100 & Very low & 104 & Low \\
\hline 5 & KK 5 & 98 & Very low & 103 & Low \\
\hline 6 & KK 6 & 112 & Low & 116 & Low \\
\hline
\end{tabular}

Based on tables 5 and 6 above, they were analyzed using the Mann-Whitney $U$ test. The following are the results of the calculations using the SPSS program.

Table 7

Ranks

\begin{tabular}{lllll}
\hline & Strategy & N & Mean Rank & Sum of Ranks \\
\hline \multirow{2}{*}{ SRL } & CCBCM & 6 & 9,50 & 57,00 \\
\cline { 2 - 5 } & Conventional & 6 & 3,50 & 21,00 \\
\cline { 2 - 5 } & Total & 12 & & \\
\hline
\end{tabular}

Table 7 shows that CCBCM interventions give higher average SRL learning ratings for students than students who get conventional counseling interventions. This means that the level of SRL students is higher after getting CCBCM intervention than students who get counseling interventions that are usually carried out by school counselors. This difference can be said to be significant if, in the Mann-Whitney test, the asymptotic significance (2-tailed) value is smaller than the alpha level of 0.05 . 
Table 8

Test statistics

\begin{tabular}{ll}
\hline & SRL \\
\hline Mann-Whitney U & .000 \\
\hline Wilcoxon W & 21.000 \\
\hline Z & -2.887 \\
\hline asymptotic significance (2-tailed) & .004 \\
\hline Exact Significance [2*(1-tailed Significance)] & $.002^{\mathrm{b}}$ \\
\hline
\end{tabular}

In table 8 , the asymptotic significance (2-tailed) value produces a value of 0.004 , which is smaller than alpha 0.05 , so we can conclude that the average of the two groups is indeed significantly different. That is, CCBCM intervention becomes a more effective intervention model to improve the level of SRL of students than counseling that is commonly done by school counselors.

\section{DISCUSSION}

The findings of the problem in this study indicate that the SRL students in the very low category by $7 \%$, the low category by $21 \%$, the moderate category by $42 \%$, the high category by $23 \%$, and the very high category by $7 \%$. The results of research on the level of SRL indicate that there are still SRL problems experienced by students. The findings of this study also serve as indicators of the need for follow-up to deal with SRL problems.

SRL is a problem that needs to get a severe response. Moreover, learning activities today emphasize online learning that requires students' ability to organize themselves in learning (Adam et al., 2017; Broadbent \& Poon, 2015; Littlejohn et al., 2016; Wong et al., 2019). At present, independent learning is an important aspect to support maximum academic achievement (Azlina, 2007; Broadbent \& Poon, 2015; Cazan, 2014; Goradia \& Bugarcic, 2017). Problems such as student failure in achieving learning goals, students who are frustrated with assignments, they are required to be able to apply new independent and self-directed learning (Zimmerman, 1990). Moreover, in today's learning, the aim is to free students from their need for teachers, so they can learn independently (Shurygin \& Krasnova, 2016). To become independent learners, they are self-governing learners (Woolfolk \& Woolfolk, 1995).

The product of this study is CCBCM for developing SRL students. The use of creative arts in cognitive behavior counseling can help students symbolically explain and describe their outside and inner world, how they interpret it, and how they feel the problems experienced (Gladding, 2016; Henderson, 2012). Besides, combining art techniques and Cognitive Behavior Counseling is effective in reducing anxiety and increasing confidence in the counselee (Parker-Bell, 2010). Another research, the integration of rational emotive behavior therapy with creative arts, is also effectively used to increase student resilience and self-esteem (Roghanchi et al., 2013). This research is proof that the integration of creative arts in Cognitive Behavior Counseling is essential to do (Meyer, 2018).

The integration of creative arts with Cognitive Behavioral Counseling requires cognitive processes and creativity (Greenberg, 2000; Peterman et al., 2015). Therefore, 
participation in counseling that involves creative arts is an opportunity for young people to see their feelings and thoughts. They can also practice solving problems by using new and unknown art materials and try to apply them creatively in an art activity.

The integration of Cognitive Behavior Counseling with the creative arts in this product is called the Creative Cognitive Behavior Counseling Model (CCBCM). CCBCM includes the following stages, namely (a) problem assessment, (b) looking for root causes that come from negative thoughts, (c) counselors and counselees identify positive and negative consequences, (d) rearranging distorted beliefs, (e) behavioral interventions. This counseling model to help students develop SRL, but can also be used to help students overcome other problems such as aggressive behavior, anxiety, and other issues by modifying CCBCM.

The creative cognitive behavior counseling model in the implementation of counseling consists of five stages. This stage guides the counselor to implement CCBCM in the counselor's effort to help the counselee get out of his problem, especially SRL. The emphasis on CCBCM is changing the counselee's mindset from negative thinking to be more positive through creative art expression. This change in the mindset can encourage the counselee to alter his behavior (Dobson \& Dobson, 2018; Ivey et al., 1987). The underlying assumption of Cognitive Behavior Counseling is the reorganization of thoughts and feelings that will bring about the reorganization of behavior in the counselee (Corey, 2018).

The first stage of CCBCM is the identification of counselee problems. Identify this problem to help the counselee express problems that are seen and felt by the counselee. Identification of issues in the counselee can be made by first building a good relationship with the counselee (Kiselica \& Englar-Carlson, 2011; Mack, 2017). At this stage, some creative arts can be used, such as visual arts, music, poetry, and writing. The counselee can be encouraged by the counselor to express the problems he feels in the form of visual art (Chibbaro \& Camacho, 2011), music (Situmorang, 2018), poetry (Brillantes-Evangelista, 2013), and writing (Crocket, 2010). The results of the identification of problems at this stage, according to Albert Ellis's view, are classified as activation events (A) in ABC format (Corey, 2018). The ABC format itself consists of $\mathrm{A}$ (Activating event), B (belief), and $\mathrm{C}$ (emotional and behavioral consequences) (Corey, 2018).

The second stage of CCBCM is to find the root of the problem that has negative thoughts. The issue presented is a problem that is seen and felt by the counselee, but the counselee may express it is not the root of the counselee's problem. Based on the CBC's view, the source of the counselee's problem lies in the cognitive of the counselee, which gives rise to negative thoughts (Craske, 2014; Dobson \& Dobson, 2018). Albert Ellis's view, this is a belief (B), which Ellis divides it into two, namely negative and positive thoughts (Corey, 2018; Ivey et al., 1987). At this stage, the counselor helps the counselee to realize negative dreams that are the cause of the low SRL by using ABC format media.

The third stage of CCBCM is the counselor, and counselee identifies the negative consequences of the counselee's problem. Albert Ellis categorizes this element as a 
Consequence (C) both in the form of behavior and feelings (Corey, 2018; Malkinson, 2010). Identifying the counselee's consequences when they think negatively will help the counselee realize that his mind will have negative consequences if it continues. At this stage, identify the negative consequences of the counselee's problem using $\mathrm{ABC}$ format media.

The fourth stage of CCBCM is to rearrange distorted beliefs. This stage is the core stage of the counseling process carried out. The counselor helps the counselee to realize his negative thoughts and replace them with positive thoughts. These positive thoughts can bridge the counselee to also behave positively according to the goals to be achieved by the counselee (Corey, 2018; Ivey et al., 1987; Ruggiero et al., 2014). The process of changing negative thought patterns into more positive ones requires active counselee participation to be able to change according to the counseling goals.

Changing the counselee's negative mindset to become more definite can be achieved by the counselor with the implementation of two dramas. The drama has a goal to increase the involvement and motivation of counselees to overcome their problems (Karnezi, 2014). The drama becomes one of the creative arts that can be combined with CBC to reduce aggressive behavior through anger management techniques (Blacker et al., 2008). One drama, the counselor, conditions the counselee to think negatively. In one other drama, the counselor conditions the counselee to think positively. The results from the drama simulation, the counselor can help the counselee to reflect on the drama simulation that has been played and can make the drama as a model for positive thinking.

In addition to the two dramas, the counselor can also maximize visual arts to help the counselee change his negative thought patterns into positive ones. Art, for example, visual art, is used to answering criticisms of the CBC process, which are considered too abstract, especially the counselor is an adolescent (Gladding, 2011, 2016; Morris, 2014). Visual art media such as drawing, painting, making symbolic objects from materials, and collages are proven to be used to help counselees reduce self-harming behavior (Whisenhunt \& Kress, 2013). The counselor can ask the counselee to describe his psychological condition on a paper when the counselee thinks negatively. Then the counselor also encourages the counselee to express the mental health if the counselee seems to think positively. As a result of that description, the counselor can facilitate the counselee to change the mindset of negative and positive thoughts.

The fifth stage of CCBCM is the behavioral intervention. At this stage, the counselor encourages the counselee to make a commitment to the change in his mindset and bring up in the form of behavior (Aharonovich et al., 2008). This commitment is essential for the counselee to remain consistent in displaying more positive action as a result of changing the mindset of the counselee, who initially thinks negatively to be positive.

The CCBCM stage indicates that there is a creative art at each step of the counseling. Creative arts at each stage of CCBCM are useful to maximize the counseling model to help counselees get out of their problems (Sherwood, 2018). Some literature calls it cognitive-behavioral art therapy (Rosal, 2001, 2016). The creative aspects of CCBCM 
have different effects on counseling services so that the counselee is happy and has a high interest in following the counseling process.

Several previous studies have shown that the combination of $\mathrm{CBC}$ with creative arts can reduce counselee problems. One study shows that the integration of $\mathrm{CBC}$ with psychodrama can help counselees relieve moderate depression (Hamamci, 2006). However, this research has not explicitly identified the combination of creative arts with CBC to address the problem of self-regulated learning. The study also mentions psychodrama explicitly as a creative art that supports the effectiveness of CBC. In the last few decades, psychodrama has become one of the promising creative arts to improve the quality of counseling services (Orkibi \& Feniger-Schaal, 2019).

Other studies suggest that the use of music can support the effectiveness of CBC to reduce millennial's academic anxiety (Situmorang et al., 2018). In this study, they are using active and passive music therapy as a creative art that supports $\mathrm{CBC}$ to reduce millennial's academic anxiety. The results showed that passive music therapy is more effective than active music therapy to support the effectiveness of $\mathrm{CBC}$ to reduce millennial's academic anxiety. The music itself becomes a creative arts modality that has the potential to help successful counseling (Gladding, 2011, 2016).

The limitation of this research lies in the limited product trials. Thus, the reliability of CCBCM cannot be generalized broadly that CCBCM can be used to improve students' SRL. Therefore, it is recommended in future studies to conduct more extensive trials to test the reliability of CCBCM for developing students' SRL. The influence of CCBCM on every aspect of SRL also needs to be identified to obtain more comprehensive research findings.

\section{CONCLUSION}

SRL is one aspect that can support student development optimally, both in the academic and non-academic fields. The problem of SRL hurts various aspects of adolescent development if it does not get severe treatment. One effort that can be done by the counselor is the implementation of $\mathrm{CBC}$ combined with creative art, which in this study is called CCBCM. Creative arts responds to criticism of CBC, which is an approach that is too abstract counseling. Thus, the implementation of creative art in $\mathrm{CBC}$ can help the counselee more clearly understand the problems and decisions taken to get out of the problem. The results of this study conclude that CCBCM is categorized as feasible for counselors to help counselees improve SRL. Besides, CCBCM can also effectively to enhance student SRL. Counselors can adapt CCBCM practices as counselor strategies to improve SRL students in schools. The limitation of this research lies in the trial of products that do not yet involve research subjects on a large scale. Thus, the generalization of research results is not yet broad in scope. The findings of this study should be the next research reference to integrate specific creative arts with $\mathrm{CBC}$ to improve each component of SRL.

\section{REFERENCES}

Adam, N. L., Alzahri, F. B., Cik Soh, S., Abu Bakar, N., \& Mohamad Kamal, N. A. (2017). Self-Regulated learning and online learning: A systematic review. Lecture Notes 
in Computer Science (Including Subseries Lecture Notes in Artificial Intelligence and Lecture Notes in Bioinformatics), 10645 LNCS, 143-154. https://doi.org/10.1007/9783-319-70010-6_14

Aharonovich, E., Amrhein, P. C., Bisaga, A., Nunes, E. V., \& Hasin, D. S. (2008). Cognition, Commitment Language, and Behavioral Change Among Cocaine-Dependent Patients. Psychology of Addictive Behaviors, 22(4), 557-562. https://doi.org/10.1037/a0012971

Alhadi, S., \& Saputra, W. N. E. (2018). Creative Cognitive-Behavior Counseling (CCBC): Optimalisasi Seni Kreatif dalam Konseling. Proceeding of The 8th University Research Colloquium 2018: Bidang Pendidikan, Humaniora Dan Agama, 198-204.

Azlina, M. K. (2007). Self-regulated learning and academic achievement in Malaysian undergraduates. International Education Journa\, 8(1), 221-228. http://iej.com.au

Banicki, K. (2014). Positive psychology on character strengths and virtues. A disquieting suggestion. New Ideas in Psychology, 33(1), 21-34. https://doi.org/10.1016/j.newideapsych.2013.12.001

Bjork, R. A., Dunlosky, J., \& Kornell, N. (2013). Self-Regulated Learning: Beliefs, Techniques, and Illusions. Annual Review of Psychology, 64(1), 417-444. https://doi.org/10.1146/annurev-psych-113011-143823

Blacker, J., Watson, A., \& Beech, A. R. (2008). A combined drama-based and CBT approach to working with self-reported anger aggression. 18, 129-137. https://doi.org/10.1002/cbm

Borg, W. R., \& Gall, M. D. (1983). Educational Research, an Introduction. Longman.

Brillantes-Evangelista, G. (2013). An evaluation of visual arts and poetry as therapeutic interventions with abused adolescents. Arts in Psychotherapy, 40(1), 71-84. https://doi.org/10.1016/j.aip.2012.11.005

Broadbent, J., \& Poon, W. L. (2015). Self-regulated learning strategies \& academic achievement in online higher education learning environments: A systematic review. Internet and Higher Education, 27, 1-13. https://doi.org/10.1016/j.iheduc.2015.04.007

Bruso, J. L., \& Stefaniak, J. E. (2016). The Use of Self-Regulated Learning Measure Questionnaires as a Predictor of Academic Success. TechTrends, 60(6), 577-584. https://doi.org/10.1007/s11528-016-0096-6

Cazan, A.-M. (2014). Self-Regulated Learning and Academic Achievement in the Context of Online Learning Environments. The 10th International Scientific Conference ELearning and Software for Education, 90-95. https://doi.org/10.12756/2066-026X-14153

Cetin, B. (2015). Academic Motivation And Self-Regulated Learning In Predicting Academic Achievement in College. Journal of International Education Research (JIER), 11(2), 95-106. https://doi.org/10.19030/jier.v11i2.9190 
Chibbaro, J., \& Camacho, H. (2011). Creative Approaches to School Counseling: Using the Visual Expressive Arts as an Intervention. Georgia School Counselors Association Journal, 18(1), 41-44.

Cole, H. P., \& Sarnoff, D. (1980). Creativity and Counseling. The Personnel and Guidance Journal, 59(3), 140-146. https://doi.org/10.1002/j.21644918.1980.tb00518.x

Corey, G. (2018). Theory and practice of counseling and psychotherapy. Cengage Learning, Inc.

Craske, M. G. (2014). Cognitive-behavioral therapy. In G. R. VandenBos, E. Meidenbauer, \& J. Frank-McNeil (Eds.), Psychotherapy theories and techniques: A reader (pp. 79-86). American Psychological Association.

Crocket, K. (2010). Rescuing speech: Teaching a writing aesthetic for counseling practice. Journal of Poetry Therapy, 23(2), 73-86. https://doi.org/10.1080/08893675.2010.482810

de Boer, H., Donker-Bergstra, A. S., \& Kostons, D. D. N. M. (2013). Effective strategies for self-regulated learning: A meta-analysisEffective strategies for selfregulated learning: A meta-analysis. Groningen, NL: GION/RUG.

Dent, A. L., \& Koenka, A. C. (2016). The Relation Between Self-Regulated Learning and Academic Achievement Across Childhood and Adolescence: A Meta-Analysis. Educational Psychology Review, 28(3), 425-474. https://doi.org/10.1007/s10648-0159320-8

Dobson, D., \& Dobson, K. S. (2018). Evidence-based practice of cognitive-behavioral therapy. Guilford Publications.

Gillham, J., Adams-Deutsch, Z., Werner, J., Reivich, K., Coulter-Heindl, V., Linkins, M., Winder, B., Peterson, C., Park, N., Abenavoli, R., Contero, A., \& Seligman, M. E. P. (2011). Character strengths predict subjective well-being during adolescence. Journal of Positive Psychology, 6(1), 31-44. https://doi.org/10.1080/17439760.2010.536773

Gladding, S. T. (1992). Counseling as an art: The creative arts in counseling. American Association for Counseling and Development, 5999 Stevenson Avenue, Alexandria.

Gladding, S. T. (2011). Using Creativity and the Creative Arts in Counseling: An International Approach. Türk Psikolojik Danışma ve Rehberlik Dergisi, 4(35), 1-7. https://doi.org/10.17066/pdrd.30360

Gladding, S. T. (2016). The creative arts in counseling. American Counseling Association.

Goradia, T., \& Bugarcic, A. (2017). Can self-regulated learning strategies improve academic achievement in online higher education learning environments? Advances in Integrative Medicine, 4(1), 36-37. https://doi.org/10.1016/j.aimed.2017.04.004

Greenberg, R. L. (2000). The Creative Client in Cognitive Therapy. Journal of Cognitive Psychotherapy, 14(2), 163-174. https://doi.org/10.1891/0889-8391.14.2.163 
Hagger, M. S., Wood, C. W., Stiff, C., \& Chatzisarantis, N. L. D. (2010). Selfregulation and self-control in exercise: The strength-energy model. International Review of Sport and Exercise Psychology, 3(1), 62-86. https://doi.org/10.1080/17509840903322815

Hamamci, Z. (2006). Integrating psychodrama and cognitive behavioral therapy to treat moderate depression. Arts in Psychotherapy, 33(3), 199-207. https://doi.org/10.1016/j.aip.2006.02.001

Heatherton, T. F., \& Wagner, D. D. (2011). Cognitive neuroscience of self-regulation failure. Trends in Cognitive Sciences, 15(3), 132-139. https://doi.org/10.1016/j.tics.2010.12.005

Henderson, D. A. (2012). The creative arts in counseling. In Humanistic Perspectives on Contemporary Counseling Issues (pp. 63-83). https://doi.org/10.4324/9780203838280

Hofmann, W., Schmeichel, B. J., \& Baddeley, A. D. (2012). Executive functions and self-regulation. Trends in Cognitive Sciences, 16(3), 174-180. https://doi.org/10.1016/j.tics.2012.01.006

Ivey, A. E., Ivey, M. B., \& Simek-Downing, L. (1987). Counseling and psychotherapy: Integrating skills, theory, and practice. In Counseling and psychotherapy: Integrating skills, theory, and practice. http://ovidsp.ovid.com/ovidweb.cgi?T=JS\&PAGE=reference $\& D=p s y c 3 \& N E W S=N \& A$ $\mathrm{N}=1987-97374-000$

Jacobs, E. E. (1992). Creative counseling techniques: An illustrated guide. Psychological Assessment Resources Incorporated.

Karnezi, H. (2014). Cognitive Behavior Drama: An Innovative Intervention Model that Combines Established Psychological Methods with the Art Form of Drama to Provide Young Children on the Autism Spectrum with the Motivation and Confidence to Overcome Their Fears. Advances in Research, 2(7), 393-408. https://doi.org/10.9734/air/2014/8643

Keyser, J. N., \& Viljoen, M. C. (2015). Self-Regulated Learning As Predictor of Academic Performance. Journal for New Generation Sciences, 13(3), 87-100.

Kiselica, M. S., \& Englar-Carlson, M. (2011). Establishing Rapport with Boys in Individual Counseling and Psychotherapy: A Male-Friendly Perspective. In M. S. Kiselica, M. Englar-Carlson, \& A. M. Horne (Eds.), Counseling Troubled Boys: A Guidebook for Professionals (pp. 79-96). Routledge.

Littlejohn, A., Hood, N., Milligan, C., \& Mustain, P. (2016). Learning in MOOCs: Motivations and self-regulated learning in MOOCs. Internet and Higher Education, 29, 40-48. https://doi.org/10.1016/j.iheduc.2015.12.003

Lucieer, S. M., Jonker, L., Visscher, C., Rikers, R. M. J. P., \& Themmen, A. P. N. (2016). Self-regulated learning and academic performance in medical education. Medical Teacher, 38(6), 585-593. https://doi.org/10.3109/0142159X.2015.1073240 
Mack, W. A. (2017). Developing a Helping Relationship with Counselees. In J. F. MacArthur (Ed.), Counseling: How to Counsel Biblically (pp. 101-114). Nelson Reference \& Electronic.

Malkinson, R. (2010). Cognitive-behavioral grief therapy: The ABC model of rationalemotion behavior therapy. Psihologijske Teme, 19(2), 289-305.

McClelland, M. M., \& Cameron, C. E. (2011). Self-regulation and academic achievement in elementary school children. In New directions for child and adolescent development (Vol. 2011, Issue 133, pp. 29-44). https://doi.org/10.1002/cd.302

McClelland, M. M., \& Wanless, S. B. (2012). Growing Up With Assets and Risks: The Importance of Self-Regulation for Academic Achievement. Research in Human Development, 9(4), 278-297. https://doi.org/10.1080/15427609.2012.729907

McGrath, R. E. (2015). Character strengths in 75 nations: An update. Journal of Positive Psychology, 10(1), 41-52. https://doi.org/10.1080/17439760.2014.888580

Meyer, D. (2018). Cognitive-Behavioral Therapy. In S. Degges-White \& N. L. Davis (Eds.), Expressive Arts Into Counseling Practice (pp. 49-76). Springer Publishing Company.

Morris, F. J. (2014). Should art be integrated into cognitive behavioral therapy for anxiety disorders? Arts in Psychotherapy, 41(4), 343-352. https://doi.org/10.1016/j.aip.2014.07.002

Mukhid, A. (1998). Strategi self-regulated learning (perspektif teoritik). Journal of Educational Psychology, 82(1), 33-40.

Niemiec, R. M., \& Wedding, D. (2014). Positive psychology at the movies: Using films to build virtues and character strengths. Hogrefe Publishing.

Nur Hidayah. (2013). Online Cognitive Behavioral Counseling Model to Improve Junior High School Students' Self-regulated Learning. THE INTERNATIONAL CONFERENCE on New Careers in New Era.

Oliveira, C., Nunes, M. F. O., Legal, E. J., \& Noronha, A. P. P. (2016). Subjective Well-Being: Linear Relationships to Character Strengths. Revista Avaliação Psicológica, 15(2), 177-185. https://doi.org/10.15689/ap.2016.1502.06

Orkibi, H., \& Feniger-Schaal, R. (2019). Integrative systematic review of psychodrama psychotherapy research: Trends and methodological implications. PLOS ONE, 14(2), 126. https://doi.org/10.1371/journal.pone.0212575

Ormrod, J. E., Anderman, E. M., \& Anderman, L. H. (2016). Educational psychology: Developing learners. Pearson.

Pajares, F. (2002). Gender and perceived self-efficacy in self-regulated learning. Theory into Practice, 41(2), 116-125. https://doi.org/10.1207/s15430421tip4102_8

Parker-Bell, B. (2010). Art Th erapy with Children and Adolescents: Inspiring Creativity and Growth. In C. L. Norton (Ed.), Innovative interventions in child and adolescent mental health (pp. 30-47). Routledge. 
Peterman, J. S., Read, K. L., Wei, C., \& Kendall, P. C. (2015). The Art of Exposure: Putting Science Into Practice. Cognitive and Behavioral Practice, 22(3), 379-392. https://doi.org/10.1016/j.cbpra.2014.02.003

Pintrich, P. R., \& De Groot, E. V. (1990). Motivational and self-regulated learning components of classroom academic performance. Journal of Educational Psychology, 82(1), 33-40. https://doi.org/10.1007/BF02338175

Plucker, J. A., Beghetto, G. T., \& Dow, R. A. (2004). The Relation Between SelfBeliefs and Academic Achievement: A Meta-Analytic Review The Relation Between Self-Beliefs and Academic Achievement: A Meta-Analytic Review. Educational Psychologist, 39(July 2015), 111-133. https://doi.org/10.1207/s15326985ep3902

Roghanchi, M., Mohamad, A. R., Mey, S. C., Momeni, K. M., \& Golmohamadian, M. (2013). The effect of integrating rational emotive behavior therapy and art therapy on self-esteem and resilience. Arts in Psychotherapy, 40(2), 179-184. https://doi.org/10.1016/j.aip.2012.12.006

Rosal, M. (2001). Cognitive-behavioral art therapy. In J. A. Rubin (Ed.), Approaches to art therapy: Theory and technique (pp. 210-225). Routledge Taylor \& Francis Group.

Rosal, M. (2016). Cognitive-behavioral art therapy revisited. In D.E. Gussak \& M.L. Rosal (Ed.), The Wiley handbook of art therapy (pp. 68-76). Routledge.

Rosen, C. M., \& Atkins, S. S. (2014). Am I Doing Expressive Arts Therapy or Creativity in Counseling? Journal of Creativity in Mental Health, 9(2), 292-303. https://doi.org/10.1080/15401383.2014.906874

Rosen, J. A., Glennie, E. J., Dalton, B. W., Lennon, J. M., \& Bozick, R. N. (2010). Noncognitive Skills in the Classroom: New Perspectives on Educational Research. In Noncognitive Skills in the Classroom: New Perspectives on Educational Research. RTI International. https://doi.org/10.3768/rtipress.2010.bk.0004.1009

Ruggiero, G. M., Ammendola, E., Caselli, G., \& Sassaroli, S. (2014). REBT in Italy: Dissemination and Integration with Constructivism and Metacognition. Journal of Rational - Emotive and Cognitive - Behavior Therapy, 32(3), 183-197. https://doi.org/10.1007/s10942-013-0177-9

Saputra, W. N. E., Da Costa, A., \& Alhadi, S. (2018). Creative Solution Focused Counseling Models (CSFCM): Strategi Kreatif untuk Mengembangkan Self-regulated Learning Siswa. Jurnal Kajian Bimbingan Dan Konseling, 3(4), 162-170. https://doi.org/10.17977/um001v3i42018p162

Schunk, D. H. (2012). Learning theories an educational perspective sixth edition. Pearson.

Sherwood, P. (2018). Creative Approaches to CBT: Art Activities for Every Stage of the CBT Process. Jessica Kingsley Publishers.

Shurygin, V. Y., \& Krasnova, L. A. (2016). Electronic learning courses as a means to activate students' independent work in studying physics. International Journal of 
Environmental and Science Education, 11(8), 1743-1751. https://doi.org/10.12973/ijese.2016.551a

Situmorang, D. D. B. (2018). How amazing music therapy in counseling for millennials. The International Journal of Counseling and Education, 3(2), 73-80. https://doi.org/https://doi.org/10.23916/0020180313220

Situmorang, D. D. B., Mulawarman, M., \& Wibowo, M. E. (2018). Comparison of the Effectiveness of CBT Group Counseling with Passive vs Active Music Therapy to Reduce Millennials Academic Anxiety. International Journal of Psychology and Educational Studies, 5(3), 51-62. https://doi.org/10.17220/ijpes.2018.03.005

Sun, Z., Xie, K., \& Anderman, L. H. (2018). The role of self-regulated learning in students' success in flipped undergraduate math courses. Internet and Higher Education, 36, 41-53. https://doi.org/10.1016/j.iheduc.2017.09.003

T. Vaughn, M. (2014). Teaching Self-Regulation Skills to Improve Academic Achievement. International Journal for Cross-Disciplinary Subjects in Education, 5(1), 1618-1625. https://doi.org/10.20533/ijcdse.2042.6364.2014.0227

Whisenhunt, J. L., \& Kress, V. E. (2013). The Use of Visual Arts Activities in Counseling Clients Who Engage in Nonsuicidal Self-Injury. Journal of Creativity in Mental Health, 8(2), 120-135. https://doi.org/10.1080/15401383.2013.792669

Wolters, C. A., \& Hussain, M. (2015). Investigating grit and its relations with college students' self-regulated learning and academic achievement. Metacognition and Learning, 10(3), 293-311. https://doi.org/10.1007/s11409-014-9128-9

Wong, J., Baars, M., Davis, D., Van Der Zee, T., Houben, G. J., \& Paas, F. (2019). Supporting Self-Regulated Learning in Online Learning Environments and MOOCs: A Systematic Review. International Journal of Human-Computer Interaction, 35(4-5), 356-373. https://doi.org/10.1080/10447318.2018.1543084

Woolfolk, A. E., \& Woolfolk, A. H. (1995). Educational psychology. Allyn \& Bacon.

Yasmin, Natasha; Khan, W. (2017). Character strengths and subjective well-being: An exploratory study of Indian youth. Indian Journal of Positive Psychology, 8(2), 174177. https://doi.org/https://doi.org/10.15614/ijpp\%2F2017\%2Fv8i2\%2F157140

Zimmerman, B. J. (1989). A Social Cognitive View of Self-Regulated Academic Learning. Journal of Educational Psychology, 81(3), 329-339. https://doi.org/10.1037/0022-0663.81.3.329

Zimmerman, B. J. (1990). Self-Regulated Learning and Academic Achievement: An Overview. Educational Psychologist, 25(1), 3-17. https://doi.org/10.1207/s15326985ep2501 